\title{
IAMJ
}

INTERNATIONAL

AYURVEDIC

MEDICAL JOURNAL

Research Article

ISSN: 2320-5091

Impact Factor: 6.719

\section{CLINICAL STUDY ON THERAPEUTIC EFFECT OF DASHAMOOLA KSHEERAPAKA AND DHANVANTARI TAILA MATRA BASTI IN UDAVARTINI YONIVYAPAD W.S.R TO DYSMENORRHEA}

\author{
Arpana Jain ${ }^{1}$, Ramadevi G', Vidya Ballal ${ }^{3}$ \\ ${ }^{1}$ Assistant professor, ${ }^{2}$ Professor, ${ }^{3}$ Associate Professor \\ Department of PG \& PhD Studies in PT\&SR, SDM college of Ayurveda, Udupi, Karnataka, India
}

Corresponding Author: arpanajainsdm@gmail.com

https://doi.org/10.46607/iamj0508122020

(Published online: December 2020)

Open Access

(C) International Ayurvedic Medical Journal, India 2020

Article Received: 11/11/2020 - Peer Reviewed: 16/11/2020 - Accepted for Publication: 19/11/2020

\section{Check for updates}

\begin{abstract}
Women's health is having prime importance for the wellbeing of the family and society. Any physical and physiological disturbance due to today's stressful life affects her reproductive life and career. Udavartini or dysmenorrhea is affecting $50 \%$ of the woman and is one of the most common clinical entities encountered in regular practice by the gynecologists. Therefore, a complete, comprehensive and holistic approach toward its understanding and treatment is the need of the hour. In the present study Dashamoola Ksheerapaka orally and Dhanvantara Taila Matra Basti has been tried in patients for the evaluation of efficacy. After the treatment, the results obtained showed significant improvement in almost all the parameters. It was observed at the end of treatment very significant relief from the intensity, duration of pain, nausea, headache, anorexia, constipation, and fatigue.
\end{abstract}

Keywords: Udavartini Yonivyapad, Dysmenorrhea, Dashamoola Ksheerapaka, Dhanvantara taila matra vasti.

\section{INTRODUCTION}

With the advent of new millennium and the herald of high-tech era, women's status expected to reach new horizons both socially and psychologically. Some of the physiological problems hinder her mentally and physically which disturbs her zeal for competing in this millennium. The commonest disturbing factor is 
painful menstruation. Onset of Artava (Menstruation) marks the starting epoch of reproductive life in women. Most of the women experience minor psychological and somatic changes for a few days preceding menstruation and during those days. Once the menstruation is over, these menstrual molimina will disappear leaving behind an anxiety free well beingness in lady. Udavartini Yonivyapath is one such condition caused because of Viloma Gati (Upward movement) of Vata due to Vegadharana (Withholding natural urges) having Pratyatma Lakshana (classical features) as Krichra Raja (Painful menstruation) and Artava Sa Vimukte Labhate Sukham. ${ }^{1}$ In modern perspective it is correlated with dysmenorrhoea which is characterized by severe pain during menstruation. Dysmenorrhea ${ }^{2}$ is a common pathological condition that affects approximately $50 \%$ of menstruating women, disturbing their daily routines. In the first year after menarche $38 \%$ of girls develop dysmenorrheal pain. In the 2 nd and $3 \mathrm{rd}$ year $20 \%$ experience pains related to menstruation. About $80 \%$ of women develop dysmenorrhoea within 3 years of menarche. In Ayurveda Acharyas says, 'Sarveshveteshu Shuleshu Prayena Pavanah Prabhuh'. Means Vata is the causative factor for all kinds of pain, which is evident by the saying that Yonivyapath occurs due to morbid Vata Dosha. Especially Apana Vayu has been given prime importance in Gynecological disorders as it is the governing force of menstruation since its Prakutha Karmas are Shukra, Artava, Shakruth, Mootra and Garbha nishkramana ${ }^{3}$. Pain is body's most important alarm system because it draws attention to the fact that something is at fault, it cannot be adequately defined, identified, or measured by an observer. Hence pain has become biggest problem since the beginning of mankind. All the system of medicine has taken origin in search of the method to relieve the pain.

Though modern medicine has made an unbelievable progress in understanding "dysmenorrhea", no new progress has been made in the line of management. Moreover, the principal drugs i.e. NSAIDS, used which aggravates gastrointestinal upsets experienced during menstruation, and also produce side effects like headache, dizziness, drowsiness and many others in sensitive individuals, which restrict their use. Hence an attempt has been made here to treat this condition with Ayurvedic drugs mentioned in Ayurvedic classics. Methodology: The present study was carried out on 10 patients attending OPD of SDMCA \& H, Udupi.

Aims and objectives of the Study: To evaluate the effect of Dashamola Ksheerapaka \& Dhanvantara Taila Matra Vasti in Udavartini Yonivyapad.

Source of data: 10 patients suffering from Udavartini Yonivyapad were selected for the study from OPD and IPD of S.D.M Ayurveda Hospital, Kuthpady, Udupi.

Study design: It is a single blind clinical study with a pre-test \& post-test design.

Method of data collection: 10 patients suffering from Udavartini Yonivyapad were administered with Dashamoola Ksheerapaka and Dhanvantara Taila Matra Vasti.

A special format was prepared with all points of history taking, physical examination and laboratory investigations, patients were analysed and selected accordingly.

\section{Inclusion Criteria:}

- Patients between the ages of 16-40 years.

- Patients with 'Pratyatma Lakshana's' of Udavartini Yonivyapath.

- Primary and secondary dysmenorrhoea

Exclusion Criteria:

- Patients with severe Anaemia ( $\mathrm{Hb} \%-<8 \%)$.

- Patients with systemic diseases like diabetes, tuberculosis. etc

- Malignant conditions

- Any uterine abnormality [congenital]

Intervention: Patients selected were administered with Dhanvantara Taila Matra Vasti $60 \mathrm{ml}$ for 7 days along with Dashamoola Ksheerapaka $50 \mathrm{ml}$ twice a day for 1 month orally after cessation of menstruation.

Duration of the study: 5 Months

Assessment: BT- $1^{\text {st }}$ day of menstrual cycle, AT 1: first day of $2^{\text {nd }}$ menstrual cycle, AT 2: first day $3^{\text {rd }}$ menstrual cycle, AT 3: first day of $5^{\text {th }}$ menstrual cycle 
Table 1: Assessment Criteria:

\begin{tabular}{|c|c|c|c|c|c|}
\hline Criteria & Scorings & BT & AT- 1 & AT-2 & AT-3 \\
\hline Pain Intensity & $\begin{array}{l}0 \text { Menstruation is not painful and daily activity is unaffected. } \\
1 \text { Menstruation is painful but daily activity is not affected. } \\
2 \text { Menstruation is painful and daily activity is affected. Anal- } \\
\text { gesic drug is needed. } \\
3 \text { Menstruation is so painful that patient is unable to do even } \\
\text { the routine work and has to miss class / office during men- } \\
\text { ses. Has to take analgesic, but without much relief. }\end{array}$ & & & & \\
\hline Duration & $\begin{array}{ll}0 & \text { No pain during menstruation } \\
1 & \text { Pain persists for less than } 12 \mathrm{~h} 2 \\
2 & \text { Pain persists for } 12-24 \mathrm{~h} \\
3 & \text { Pain persists for more than } 24 \mathrm{~h}\end{array}$ & & & & \\
\hline Nature & Spasmodic/Colic/ Any Others & & & & \\
\hline Site & $\begin{array}{l}\text { Lower Abdomen Pain, Back Pain, Pain Radiating to thighs } \\
0 \text { No Pain } \\
1 \text { Presence of all three for less than } 1 \mathrm{~h} / \text { any two features } \\
\text { for less than } 6 \mathrm{H} \text { / any One feature for less than } 12 \mathrm{H} \\
2 \text { Presence of all three for } 1-2 \mathrm{H} / \text { any Two features for 6- } \\
12 \mathrm{H} \text { / any one feature for more than } 12 \mathrm{H} \\
3 \text { Presence of all three for more than } 2 \mathrm{H} / \text { any two fea- } \\
\text { tures for } 12-24 \mathrm{H} \text { / any One feature for more than } 24 \mathrm{H}\end{array}$ & & & & \\
\hline $\begin{array}{l}\text { Inter Menstrual } \\
\text { Pain }\end{array}$ & $\begin{array}{l}\text { Present: if yes, day of cycle/number of days- } \\
\text { Absent }\end{array}$ & & & & \\
\hline $\begin{array}{ll}\text { Amount } & \text { of } \\
\text { Blood Loss } & \end{array}$ & $\begin{array}{ll}0 & 6-7 \mathrm{Pads} / \text { Cycle } \\
1 & 4-5 \mathrm{Pads} / \mathrm{Cycle} \\
2 & 2-3 \mathrm{Pads} / \mathrm{Cycle} \\
3 & \text { SpottingOr1Pad/Cycle }\end{array}$ & & & & \\
\hline Clots & $\begin{array}{l}\text { Present: If Yes, Size- } \\
\text { Absent }\end{array}$ & & & & \\
\hline Nausea & $\begin{array}{ll}0 & \text { No Nausea } \\
1 & 2-3 \text { Times/Day } \\
2 & 4-5 \text { Times/Day } \\
3 & >5 \text { Times/Day }\end{array}$ & & & & \\
\hline Vomiting & $\begin{array}{l}0 \text { No Vomiting } \\
1 \text { Occasionally } \\
2 \text { 1-2 Times/Day } \\
3 \text { More Than 2times /Day }\end{array}$ & & & & \\
\hline Anorexia & $\begin{array}{l}0 \text { Takes a full diet and also has proper appetite at the next } \\
\text { mealtime } \\
1 \text { presence of moderate appetite and promote appearance } \\
\text { of appetite in next mealtime } \\
2 \text { presence of low appetite but delayed appearance of appe- } \\
\text { tite in next mealtime } \\
3 \text { persisting low appetite or frequent loss of appetite; una- } \\
\text { ble to consume even the minimum required diet }\end{array}$ & & & & \\
\hline Headache & $\begin{array}{l}\text { 0. No Headache } \\
\text { 1. Headache once during each menstruation; persists for less }\end{array}$ & & & & \\
\hline
\end{tabular}




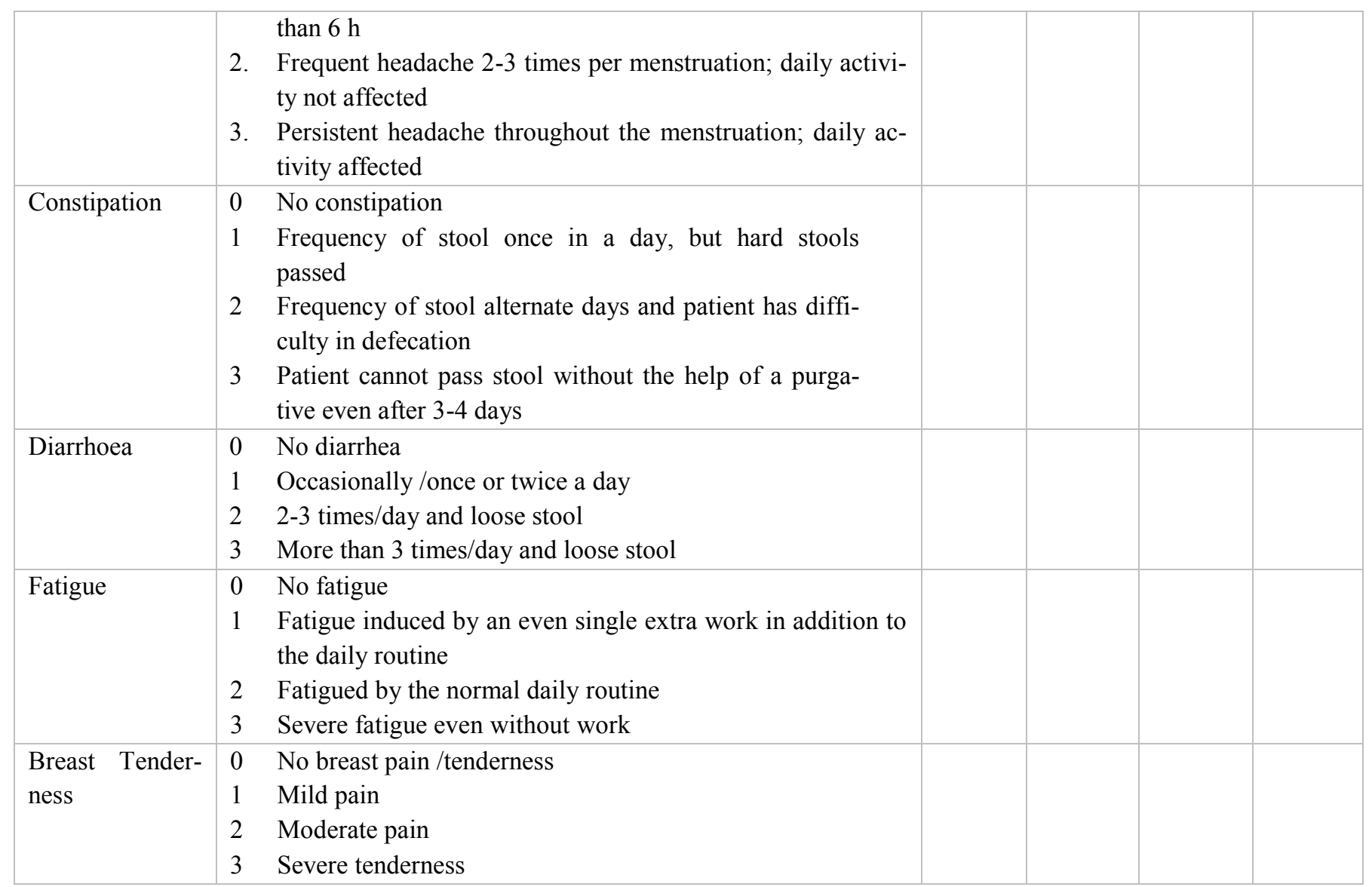

Final Assessment: Visual analogue scale ${ }^{4}$ (VAS) for pain:

The visual analog scale for pain is a straight line with one end meaning no pain and the other end meaning the worst pain imaginable. Here patient makes a point on a $10 \mathrm{~cm}$ horizontal or vertical line to indicate their pain intensity, with 0 indicating "no pain" and "10 indicating the worst possible pain".

Picture 1 : Showing VAS

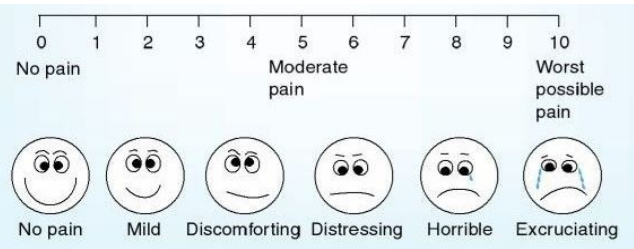

Investigations: $\mathrm{Hb} \%$, TLC, DLC, ESR, Urine routine and USG [only if required]

Observations \& Results:

Table 2: Showing effect of treatment on intensity of pain

\begin{tabular}{|c|c|c|c|c|c|c|c|c|c|}
\hline \multirow[t]{2}{*}{$\mathrm{N}$} & \multirow{2}{*}{$\begin{array}{l}\text { BT- } \\
\text { Mean }\end{array}$} & \multirow{2}{*}{\multicolumn{2}{|c|}{ AT-Mean }} & \multirow{2}{*}{$\begin{array}{l}\text { Diff } \\
\text { D }\end{array}$} & \multirow[t]{2}{*}{$\%$} & \multicolumn{4}{|c|}{ Paired $t$ test } \\
\hline & & & & & & SD & S. E & $\mathrm{t}$ & $\mathrm{P}$ \\
\hline \multirow[t]{3}{*}{10} & \multirow[t]{3}{*}{2.8} & AT1 & 0.9 & 1.90 & 67.8 & 0.31 & 0.10 & 10.58 & $<0.0001$ \\
\hline & & AT2 & 0.9 & 1.90 & 67.8 & 0.31 & 0.10 & 10.58 & $<0.0001$ \\
\hline & & AT3 & 1.1 & 1.70 & 60.7 & 0.56 & 0.17 & 7.96 & $<0.0001$ \\
\hline
\end{tabular}


The statistical analysis revealed that the mean score of intensity of pain:

$\checkmark$ Mean was 2.8 before the treatment was reduced to

0.9 in F1 \& F2,1.1 in F3and this change is statisti- cally considered as extremely significant with $\mathrm{P}$ values $<0.0001$.

Table 3: showing effect of treatment on duration of pain

\begin{tabular}{|l|l|l|l|l|l|l|l|l|l|}
\hline N & $\begin{array}{l}\text { BT- } \\
\text { Mean }\end{array}$ & \multicolumn{2}{l|}{ AT-Mean } & $\begin{array}{l}\text { Diff } \\
\text { D }\end{array}$ & $\%$ & \multicolumn{2}{l|}{ Paired t test } & \\
\hline 10 & 2.6 & AT1 & 1.1 & 1.50 & 57.6 & 0.31 & 0.10 & 9.000 & $<0.0001$ \\
\cline { 3 - 11 } & & AT2 & 1.1 & 1.50 & 57.8 & 0.31 & 0.10 & 9.000 & $<0.0001$ \\
& & AT3 & 1.3 & 1.30 & 50 & 0.48 & 0.15 & 8.510 & $<0.0001$ \\
\hline
\end{tabular}

The statistical analysis revealed that the mean score of duration of pain was:

cally considered as extremely significant with $\mathrm{P}$

$\checkmark$ Mean was 2.6 before the treatment was reduced to values $<0.0001$.

1.1 in F1 \& F2,1.3 in F3and this change is statisti-

Table 4: Showing effect of treatment on site of pain

\begin{tabular}{|c|c|c|c|c|c|c|c|c|c|}
\hline \multirow[t]{2}{*}{$\mathrm{N}$} & \multirow{2}{*}{$\begin{array}{l}\text { BT } \\
\text { Mean }\end{array}$} & \multirow{2}{*}{\multicolumn{2}{|c|}{ AT-Mean }} & \multirow{2}{*}{$\begin{array}{l}\text { Diff } \\
\text { D }\end{array}$} & \multirow[t]{2}{*}{$\%$} & \multicolumn{4}{|c|}{ Paired $t$ test } \\
\hline & & & & & & SD & S.E & $\mathrm{t}$ & $\mathrm{P}$ \\
\hline \multirow[t]{3}{*}{10} & \multirow[t]{3}{*}{2.5} & AT1 & 1.3 & 1.20 & 48 & 0.48 & 0.15 & 6.00 & 0.0002 \\
\hline & & AT2 & 1.2 & 1.30 & 52 & 0.42 & 0.13 & 8.510 & $<0.0001$ \\
\hline & & AT3 & 1.5 & 1.00 & 40 & 0.70 & 0.22 & 4.743 & 0.0011 \\
\hline
\end{tabular}

The statistical analysis revealed that the mean score of sites of pain was:

$\checkmark$ Mean was 2.5 before the treatment was reduced to tistically considered as extremely significant in F1 $\& \mathrm{~F} 2$, very significant in F3 with $\mathrm{P}$ values 0.0002 , 1.3 in F1, 1.2 in F2,1.5 in F3and this change is sta$<0.0001 \& 0.0011$ respectively.

Table 5: Showing effect of treatment on amount of blood loss

\begin{tabular}{|c|c|c|c|c|c|c|c|c|c|}
\hline \multirow[t]{2}{*}{$\mathrm{N}$} & \multirow{2}{*}{$\begin{array}{l}\text { BT } \\
\text { Mean }\end{array}$} & \multirow{2}{*}{\multicolumn{2}{|c|}{ AT-Mean }} & \multirow{2}{*}{$\begin{array}{l}\text { Diff } \\
\text { D }\end{array}$} & \multirow[t]{2}{*}{$\%$} & \multicolumn{4}{|c|}{ Paired $t$ test } \\
\hline & & & & & & SD & S.E & $\mathrm{t}$ & $\mathrm{P}$ \\
\hline \multirow[t]{3}{*}{10} & \multirow[t]{3}{*}{0.0} & AT1 & 0.0 & 0.0 & 0 & 0.0 & 0.0 & - & - \\
\hline & & AT2 & 0.0 & 0.0 & 0 & 0.0 & 0.0 & - & - \\
\hline & & AT3 & 0.0 & 0.0 & 0 & 0.0 & 0.0 & - & - \\
\hline
\end{tabular}

The statistical analysis revealed that the mean score of amounts of blood loss during menstruation:

$\checkmark$ Mean was 0.0 before the treatment, and there was no change after the treatment hence this value is not considered for statistical evaluation.

Table 6: Showing effect of treatment on nausea

\begin{tabular}{|c|c|c|c|c|c|c|c|c|c|}
\hline \multirow[t]{2}{*}{$\mathrm{N}$} & \multirow{2}{*}{$\begin{array}{l}\text { BT } \\
\text { Mean }\end{array}$} & \multirow{2}{*}{\multicolumn{2}{|c|}{ AT-Mean }} & \multirow{2}{*}{$\begin{array}{l}\text { Diff } \\
\text { D }\end{array}$} & \multirow[t]{2}{*}{$\%$} & \multicolumn{4}{|c|}{ Paired $t$ test } \\
\hline & & & & & & SD & S.E & $\mathrm{t}$ & $\mathrm{P}$ \\
\hline \multirow[t]{3}{*}{10} & \multirow[t]{3}{*}{1.6} & AT1 & 0.30 & 1.30 & 81.25 & 0.48 & 0.15 & 4.333 & 0.0019 \\
\hline & & AT2 & 0.30 & 1.30 & 81.25 & 0.48 & 0.15 & 4.333 & 0.0019 \\
\hline & & AT3 & 0.30 & 1.30 & 81.25 & 0.48 & 0.15 & 4.333 & 0.0019 \\
\hline
\end{tabular}


The statistical analysis revealed that the mean score of nausea during menstruation,

$\checkmark$ Mean was 1.6 before the treatment was reduced to

1.30in F1, F2, \& F3and this change is statistically considered as very significant with $\mathrm{P}$ values 0.0019 .

Table 7: Showing effect of treatment on vomiting

\begin{tabular}{|c|c|c|c|c|c|c|c|c|c|}
\hline \multirow[t]{2}{*}{$\mathrm{N}$} & \multirow{2}{*}{$\begin{array}{l}\text { BT } \\
\text { Mean }\end{array}$} & \multirow{2}{*}{\multicolumn{2}{|c|}{ AT-Mean }} & \multirow{2}{*}{$\begin{array}{l}\text { Diff } \\
\text { D }\end{array}$} & \multirow[t]{2}{*}{$\%$} & \multicolumn{4}{|c|}{ Paired $t$ test } \\
\hline & & & & & & SD & S.E & $\mathrm{t}$ & $\mathrm{P}$ \\
\hline \multirow[t]{3}{*}{10} & \multirow[t]{3}{*}{1.7} & AT1 & 0.5 & 1.20 & 70.5 & 0.70 & 0.22 & 4.811 & 0.0010 \\
\hline & & AT2 & 0.4 & 1.30 & 76.4 & 0.52 & 0.16 & 4.993 & 0.0007 \\
\hline & & AT3 & 0.7 & 1.00 & 58.8 & 0.67 & 0.21 & 2.372 & 0.0418 \\
\hline
\end{tabular}

The statistical analysis revealed that the mean score of vomiting during menstruation was:

$\checkmark$ Mean was 1.7 before the treatment was reduced to 0.5 in F1, 0.4 in F2, 0.7 in F3and this change is statistically considered as extremely significant in $\mathrm{F} 1$ and F2, significant in F3 with P values 0.0010 , $0.0007,0.0418$.

Table 8: Showing Effect of Treatment on Anorexia

\begin{tabular}{|c|c|c|c|c|c|c|c|c|c|}
\hline \multirow[t]{2}{*}{$\mathrm{N}$} & \multirow{2}{*}{$\begin{array}{l}\text { BT } \\
\text { Mean }\end{array}$} & \multirow{2}{*}{\multicolumn{2}{|c|}{ AT-Mean }} & \multirow{2}{*}{$\begin{array}{l}\text { Diff } \\
\text { D }\end{array}$} & \multirow[t]{2}{*}{$\%$} & \multicolumn{4}{|c|}{ Paired $t$ test } \\
\hline & & & & & & SD & S.E & $\mathrm{t}$ & $\mathrm{P}$ \\
\hline \multirow[t]{3}{*}{10} & \multirow[t]{3}{*}{1.7} & AT1 & 0.6 & 1.10 & 64.7 & 0.51 & 0.16 & 4.71 & 0.0011 \\
\hline & & AT2 & 0.6 & 1.10 & 64.7 & 0.51 & 0.16 & 4.71 & 0.0011 \\
\hline & & AT3 & 0.8 & 0.90 & 52.9 & 0.63 & 0.20 & 2.37 & 0.0414 \\
\hline
\end{tabular}

The statistical analysis revealed that the mean score for anorexia during menstruation was:

$\checkmark$ In Group C mean was 1.7 before the treatment was reduced to 0.6 in F1 \& F2, 0.8 in F3and this change is statistically considered as very significant inF1 \& F2, significant in F3 with $\mathrm{P}$ values 0.0011 in $F 1$ \& F2, 0.0414 in F3.

Table 9: Showing effect of treatment on headache

\begin{tabular}{|c|c|c|c|c|c|c|c|c|c|}
\hline \multirow[t]{2}{*}{$\mathrm{N}$} & \multirow{2}{*}{$\begin{array}{l}\text { BT } \\
\text { Mean }\end{array}$} & \multirow{2}{*}{\multicolumn{2}{|c|}{ AT-Mean }} & \multirow{2}{*}{$\begin{array}{l}\text { Diff } \\
\text { D }\end{array}$} & \multirow[t]{2}{*}{$\%$} & \multicolumn{4}{|c|}{ Paired $t$ test } \\
\hline & & & & & & SD & S.E & $\mathrm{T}$ & $\mathrm{P}$ \\
\hline \multirow[t]{3}{*}{10} & \multirow[t]{3}{*}{0.9} & AT1 & 0.3 & 0.6 & 66.6 & 0.48 & 0.15 & 2.800 & 0.0251 \\
\hline & & AT2 & 0.3 & 0.6 & 66.6 & 0.48 & 0.15 & 2.800 & 0.0251 \\
\hline & & AT3 & 0.3 & 0.6 & 66.6 & 0.48 & 0.15 & 2.800 & 0.0251 \\
\hline
\end{tabular}

The statistical analysis revealed that the mean score of headaches during menstruation: $\checkmark$ Mean was 0.9 before the treatment was reduced to 0.3 in F1, F2, \& F3 and this change is statistically considered as significant with $\mathrm{P}$ values 0.0251 .

Table 10: Showing Effect of Treatment on Constipation

\begin{tabular}{|c|c|c|c|c|c|c|c|c|c|}
\hline \multirow[t]{2}{*}{$\mathrm{N}$} & \multirow{2}{*}{$\begin{array}{l}\text { BT } \\
\text { Mean }\end{array}$} & \multirow{2}{*}{\multicolumn{2}{|c|}{ AT-Mean }} & \multirow{2}{*}{$\begin{array}{l}\text { Diff } \\
\text { D }\end{array}$} & \multirow[t]{2}{*}{$\%$} & \multicolumn{4}{|c|}{ Paired $t$ test } \\
\hline & & & & & & SD & S.E & $\mathrm{t}$ & $\mathrm{P}$ \\
\hline \multirow[t]{3}{*}{10} & 1.1 & AT1 & 0.1 & 1.00 & 90.9 & 0.31 & 0.10 & 3.00 & 0.0150 \\
\hline & & AT2 & 0.1 & 1.00 & 90.9 & 0.31 & 0.10 & 3.00 & 0.0150 \\
\hline & & AT3 & 0.2 & 0.90 & 81.8 & 0.42 & 0.13 & 2.586 & 0.0294 \\
\hline
\end{tabular}


The statistical analysis revealed that the mean score of constipation during menstruation: Mean was 1.1 before the treatment was reduced to 0.1 in $\mathrm{F} 1 \& \mathrm{~F} 2,0.2$ in F3and this change is statistically considered as significant with $\mathrm{P}$ values 0.0150 in F1 \& F2, 0.0294 in F3.

Table 11: Showing effect of treatment on Diarrhoea

\begin{tabular}{|c|c|c|c|c|c|c|c|c|c|}
\hline \multirow[t]{2}{*}{$\mathrm{N}$} & \multirow{2}{*}{$\begin{array}{l}\text { BT } \\
\text { Mean }\end{array}$} & \multirow{2}{*}{\multicolumn{2}{|c|}{ AT-Mean }} & \multirow{2}{*}{$\begin{array}{l}\text { Diff } \\
\text { D }\end{array}$} & \multirow[t]{2}{*}{$\%$} & \multicolumn{4}{|c|}{ Paired $t$ test } \\
\hline & & & & & & SD & S.E & $\mathrm{t}$ & $P$ \\
\hline \multirow[t]{3}{*}{10} & \multirow[t]{3}{*}{0.7} & AT1 & 0.1 & 0.6 & 85.7 & 0.31 & 0.10 & 1.964 & 0.0811 \\
\hline & & AT2 & 0.1 & 0.6 & 85.7 & 0.31 & 0.10 & 1.964 & 0.0811 \\
\hline & & AT3 & 0.1 & 0.6 & 85.7 & 0.31 & 0.10 & 1.964 & 0.0811 \\
\hline
\end{tabular}

The statistical analysis revealed that the mean score of duration of pain was: Mean was 0.7 before the treatment was reduced to 0.1 in F1, F2, \& F3, and this change is statistically considered as not significant with $\mathrm{P}$ values 0.0811 .

Table 12: Showing effect of treatment on fatigue

\begin{tabular}{|c|c|c|c|c|c|c|c|c|c|}
\hline \multirow[t]{2}{*}{$\mathrm{N}$} & \multirow{2}{*}{$\begin{array}{l}\text { BT } \\
\text { Mean }\end{array}$} & \multirow{2}{*}{\multicolumn{2}{|c|}{ AT-Mean }} & \multirow{2}{*}{$\begin{array}{l}\text { Diff } \\
\text { D }\end{array}$} & \multirow[t]{2}{*}{$\%$} & \multicolumn{4}{|c|}{ Paired $t$ test } \\
\hline & & & & & & SD & S.E & $\mathrm{t}$ & $\mathrm{P}$ \\
\hline \multirow[t]{3}{*}{10} & \multirow[t]{3}{*}{2.3} & AT1 & 0.7 & 1.60 & 69.5 & 0.48 & 0.15 & 9.798 & $<0.0001$ \\
\hline & & AT2 & 0.7 & 1.60 & 69.5 & 0.48 & 0.15 & 9.798 & $<0.0001$ \\
\hline & & AT3 & 0.7 & 1.60 & 69.5 & 0.48 & 0.15 & 9.798 & $<0.0001$ \\
\hline
\end{tabular}

The statistical analysis revealed that the mean score of fatigue during menstruation:

$\checkmark$ Mean was 2.3 before the treatment was reduced to

0.7 in F1, F2, \& F3 and this change is statistically considered as extremely significant with $\mathrm{P}$ values $<0.0001$.

Table 13: showing effect of treatment on breast tenderness

\begin{tabular}{|c|c|c|c|c|c|c|c|c|c|}
\hline \multirow[t]{2}{*}{$\mathrm{N}$} & \multirow[t]{2}{*}{ BT Mean } & \multirow{2}{*}{\multicolumn{2}{|c|}{ AT-Mean }} & \multirow[t]{2}{*}{ Diff d } & \multirow[t]{2}{*}{$\%$} & \multicolumn{4}{|c|}{ Paired $t$ test } \\
\hline & & & & & & SD & S.E & $\mathrm{t}$ & $\mathrm{P}$ \\
\hline \multirow[t]{3}{*}{10} & \multirow[t]{3}{*}{0.8} & AT1 & 0.5 & 0.30 & 37.5 & 0.85 & 0.27 & 1.406 & 0.1934 \\
\hline & & AT2 & 0.5 & 0.30 & 37.5 & 0.85 & 0.27 & 1.406 & 0.1934 \\
\hline & & AT3 & 0.5 & 0.30 & 37.5 & 0.85 & 0.27 & 1.406 & 0.1934 \\
\hline
\end{tabular}

The statistical analysis revealed that the mean score of breast tenderness during menstruation:

$\checkmark$ Mean was 0.8 before the treatment was reduced to 0.5 in F1, F2 \& F3and this change is statistically considered as not significant with $\mathrm{P}$ values 0.1934 .

Table 14: Showing Effect of Treatment on VAS

\begin{tabular}{|c|c|c|c|c|c|c|c|c|c|}
\hline \multirow[t]{2}{*}{$\mathrm{N}$} & \multirow{2}{*}{$\begin{array}{l}\text { BT } \\
\text { Mean }\end{array}$} & \multirow{2}{*}{\multicolumn{2}{|c|}{ AT-Mean }} & \multirow{2}{*}{$\begin{array}{l}\text { Diff } \\
\text { D }\end{array}$} & \multirow[t]{2}{*}{$\%$} & \multicolumn{4}{|c|}{ Paired $t$ test } \\
\hline & & & & & & SD & S.E & $\mathrm{T}$ & $\mathrm{P}$ \\
\hline \multirow[t]{3}{*}{10} & \multirow[t]{3}{*}{9.6} & AT1 & 2.9 & 6.70 & 69.7 & 1.66 & 0.52 & 11.21 & $<0.0001$ \\
\hline & & AT2 & 2.8 & 6.80 & 70.8 & 1.61 & 0.51 & 11.85 & $<0.0001$ \\
\hline & & AT3 & 3.3 & 6.30 & 65.6 & 1.88 & 0.59 & 9.947 & $<0.0001$ \\
\hline
\end{tabular}


The statistical analysis revealed that the mean score of VAS:

$\checkmark$ Mean was 9.6 before the treatment was reduced to 2.9in F1, 2.8 in F2, 3.3 in F3and this change is statistically considered as extremely significant with $\mathrm{P}$ values $<0.0001$.

Table 15: Showing Results

\begin{tabular}{|l|l|l|l|l|l|}
\hline S1. No & Criteria & BT- mean & AT-2 mean & P value & Inference \\
\hline 1 & Intensity of pain & 2.8 & 0.9 & $<0.0001$ & Extremely significant \\
\hline 2 & Duration of pain & 2.6 & 1.3 & $<0.0001$ & Extremely significant \\
\hline 3 & Nausea & 1.6 & 0.3 & 0.0019 & Very significant \\
\hline 5 & Anorexia & 1.7 & 0.8 & 0.0011 & Very significant \\
\hline
\end{tabular}

\section{DISCUSSION}

'Women's health needs to be front and center - it often isn't, but it needs to be'

A woman undergoes various physical and physiological changes during her reproductive period i.e. from menarche to menopause. Menstruation is one such physiological process that is taking place in woman's life that requires awareness and proper care to remain healthy. In Ayurveda, Acharyas have explained different Paricharyas (Regimen) like Dinacharya, Rutucharya etc. to maintain Swasthavastha. Other than Shodasa Samakara's, for Stree specifically different Paricharyas like Rajaswala Charya, Ritumati Charya, Garbhini Paricharyas were described. Among them 'Rajaswala Paricharya' is one which should be followed during menstruation as this keeps the woman free from menstrual ailments. Traditionally these $\mathrm{Pa}$ richaryas were followed by our ancestors hence prevalence of diseases were less during those days but in the present era people are career oriented and the life style has changed a lot from before which makes them suffer from various menstrual disorders. Udavartini is one such disorder caused due to improper regimen. Ayurveda stresses on the importance of health of woman, as she is the only one who can procreate and thus play foundation of healthy society. Ayurvedic treatment not only cures the pathologies of reproductive organ but with holistic approach treat the woman as whole, thereby improving the general health also. Udavartini can be correlated to dysmenorrhea which is a common pathological condition that affects approximately $50 \%$ of menstruating women, which causes significant discomfort $\&$ anxiety in the woman as well as her family. A systematic review of studies in developing countries performed by Harlow and Campbell (2002) has revealed that about $25-50 \%$ of adult women and about $75 \%$ of adolescents experience pain during menstruation, with $05-20 \%$ reporting severe dysmenorrhoea or pain that prevent them from ensuing day-to-day activities. Hence considering the increased prevalence rate of this disease, the present research work is planned to assess the efficacy of selected drugs on Udavartini Yonivyapad and to compare the efficacy of both Basti and oral group.

Discussion on Dashamoola Ksheerapaka,6:

Dashamoola ksheerapaka contains Bilva, Agnimantha, Shyonaka, Patala, Gambhari, Bruhati Kantakari, Shaliparni, Prisniparni, Gokshura-1 part each, Ksheera -8 parts, water -32 parts. Dashamoola Ksheera Pana has been indicated in treatment of $U d a-$ varta Yonivyapad. Most of the drugs in Dashamooa are having Madhura \& Kashaya Rasa, Laghu Ruksha Guna, Ushna Veerya, Madhura Vipaka, which mainly act on Vata Vikriti. Madhura rasa, Laghu Guna and Madhura Vipaka helps to pacify vitiated Vata, Kashaya Rasa and Ushna Veerya does Amapachana $\&$ cleanses the Srotasa. Collectively the actions of Dashamoola are Vatahara, Parshvashulahara, Shothahar, Balya, Amapachaka. Ksheera has been mentioned as Pathya for all the Yonivyapad. Ksheera 
is having Madhura Rasa, Snigdha Guna, Madhura Vipaka and it is Jeevaniya, Balya, Yonirogahara, Anulomaka in nature. Thus, when Dashamoola is processed with Ksheera, it provides Dhatu Poshana, in turn alleviates Vata, gives strength to the uterine musculature helps in normal Prasarana and Akunchana. By the above properties Dashamoola ksheerapaka is Vatanulomaka, Balya, Shothahara, Shoolahara, Amapachaka and reduces most of the discomforts produced during menstruation like fatigue, anorexia, diarrhoea, constipation thus it favors normal menstruation.

Discussion on Basti Chikitsa with Dhanvantara Taila ${ }^{7}$ :

Basti is considered as Paramaushada for the management of Vata and it is the treatment modality explained in all types of Yonivyapath. In Udavartini Yoni Vyapath there will be Viloma Gati of Vata, hence Anulomana of Vata is required which can be obtained by administration of Basti. Dhanvantara Taila mentioned in Sahasrayoga Taila Prakarana mainly consists of main ingredients like Bala, Dashamoola, Ashwagandha, Triphala, Ksheera, Tila taila etc. are having Balya, Vatanulomaka, Shothahara, Vedana sthapaka, Rasayana properties. Taila is considered as best for Vata, Tila Taila by its Teekshna, Ushna, Sukshma, Sara and Vyavayi Guna enters the Srotas clears Sroto Avarodha and allows the normal downward movement of Apana Vata. It mainly acts as Balya, Rasayana, Vataghna, Yonishoolahara, Udavartanashaka. It contains minerals like magnesium, calcium, iron, zinc, vitamins B6 \& D helps in relieving fatigue, anxiety, and headache, promotes strength to nerves and muscle. It helps in improving circulation thus it relieves the pelvic congestion and by improving immunity increases the pain threshold. It is considered as laxative and having the properties like Teekshna, Sukshma, Sara, Vyavayi and Vikasi, which relaxes the muscle and eases the pain. It has antioxidant property which prevents synthesis of prostaglandins. By the above said properties of Dhanvantara Taila we can conclude that the taken drug has the capacity of Vatahara, Rasayana, Balya, Shothahara, Shoolahara and favors the Anulomana of Apana Vata.

\section{Mode of Action of Matra Basti:}

Mode of action of Matra Basti is defined in Ayurvedic classics very well., In modern science there are three theories, which are being tried to explain the mode of action of Basti. They are -

i) Absorption through gastrointestinal system,

ii) Stimulation of enteric nervous system (ENS)

iii) System biology.

The Basti drugs are absorbed from the intestines through the rich blood supply of rectum and acts on all over the body. From capillaries and lymphatics of intestines, it will reach to systemic circulation and then will act on all the bodily organs. This theory is same as the theory given by Acharya Sushruta, says that the Virya of Basti administered through rectum reaches the whole body through the channels as the active principles in the water when poured at the root reaches the whole plant. Acharya Charaka has also described the similar view to modern theory of absorption to explain the action of Basti. As tree irrigated in its root level attains nourishment for whole tree, in the same way, Basti drugs given through Guda, because of its rich blood supply nourishes the limbs \& all the organs of the body. Whole body is composed of Srotas i.e. channels (micro and macro) from where things can (metabolites) travel. Srotas can be correlated with all the biological channels (Blood vessels, lymphatics, capillaries), pores, paracellular spaces, intercellular spaces etc. these are not restricted to organs, systems, cells, but also to the nucleus of the cells. Thus, Basti Dravya normalizes the function of Vata after reaching all over the body. Its contents act through their different chemical constituents to restore the normal menstrual physiology and thus relieve pain during menstruation. On the neuro-humoral system of body, Basti acts by stimulating CNS through ENS, by restoring the physiology at molecular level and it can also act on the inflammatory substances like prostaglandins \& vasopressin etc by the various contents of oil used which have anti-inflammatory property. It has been found that endogenous opioids which are generated in pituitary, hypothalamus as well as in peripheral tissues including GIT specially $\beta$ Endorphin's play role in regulating the secretion of pituitary hormones, 
Vasopressin, Oxytocin etc. Thus, it normalizes the neurotransmitters, hormonal \& neural pathways and relieves all the symptoms complex emerged as a result of neuro-humoral imbalances in the patients of dysmenorrhoea. Medicinal property of oil reaches to the CNS through ENS and normalizes the functions of hypothalamo-pituitary-ovarian axis \& normalizes hormonal levels. Apart from that therapeutic action of Basti on Udavartini it also does other mechanisms like, improves overall nutrition status of body, improves intestinal health and absorption, nourishes the system, increases the immunity by detoxifying the system, by action of active principle of drug it breaks the pathology. The newer approach of system biology getting popular in modern science is very much similar to holistic approach of Ayurveda. It believes that human body does not act on reductionist approach, rather it acts in holistic way. All the systems are interrelated on molecular level, and the change at molecular level on one system will affect whole the body. This theory is same as the Ayurvedic theory of Tridoshas. Dosha acts on all the organs simultaneously and its functional disturbance will influence all bodily functions. Thus, Basti will act not only on the pain, but also entire menstrual molimina's of body by normalizing the functions of Vata.

\section{CONCLUSION}

Udavartini yonivyapad (dysmenorrhoea) is one of the most common ailments in present era which affects woman both physically and mentally disturbing their daily routine and it is a common cause for absenteeism from school, college and work. In udavartini yonivyapad specially Snehana with Traivruth Sneha, Swedana with Auduka and Anupa Mamsa Rasa, Dashamoola Siddha Ksheerapana as well as Basti, Anuvasana and Uttara Basti using Vatahar Taila's have been mentioned. Along with this, main culprit of Udavartini Yonivyapad is Apana Vata, hence the general management of Apanavata Dushti mentioned by Charaka i.e. Anulomana Karma along with other Vatashamaka measures should be followed. The two drugs selected for the study, Dashamoola Ksheerapaka and Dhanvantara taila which are good
Vatashamaka Dravyas according to classics. Dashamoola is the best Tridoshahara Dravya when processed with Ksheera it acts best on Vata. And Basti has been mentioned as one of the best therapeutic procedure for alleviation of vitiated Vata. These drugs showed extremely significant improvement in Intensity $\&$ duration of pain $(65 \%$ and $55 \%$ ). Nausea and anorexia also showed significant improvement. Not much change was noticed in breast tenderness, diarrheoa and on amount of blood loss.

\section{REFERENCES}

1. Agnivesha, Charaka Samhita Revised By Charaka \& Dridabala, With Ayurveda Dipikacomentary By Chakrapanidatta, Foreword By Acharya Yadav Ji Trikamji. Edition- 2013, Varanasi: Choukhamba Surabharathi Prakashana, Chikitssthana, Pp-738, P-635.

2. D. C. Dutta, Hiralal Konar, Textbook Of Gynecology, New Central Book Agency (P) Ltd.,Calcutta, 4th Edition 2003, Pp-606, P-169.

3. Vagbhata, Ashtanga Hrudayam, With Sarvangasundari, And Ayurvedrasayana Comentory, Edited By Krsna Ramachandra Shashtry, Varanasi: Chaukhamba Surabharati Prakashana, Suthrasthana 12/9, Pp-956, P193.

4. Www.Medscape.Com

5. Agnivesha, Charaka Samhita Revised By Charaka \&Dridabala, With Ayurveda Dipikacomentary By Chakrapanidatta, Foreword By Acharya Yadav Ji Trikamji. Edition- 2013, Varanasi: Choukhamba Surabharathi Prakashana, Chikitssthana 30/110,111.

6. Vagbhata, Astanga Sangraha With Indu Tika,Edited By Prof. Jyothi Mitra And Dr. Shivaprasad Sharma, Chaukamba Kishnadas Academy, Varanasi, Uttara Tantra 39/29, Pp-965,P-837.

7. Sharma Ram Nivas \& Sharma Surendra, Sahasrayogam, Varanasi: Chowkhamba Sanskrita Pratistan, 2009, Pp-318, P-74,75

\section{Source of Support: Nil Conflict of Interest: None Declared}

How to cite this URL: Arpana Jain et al: Clinical Study On Therapeutic Effect Of Dashamoola Ksheerapaka And Dhanvantari Taila Matra Basti In Udavartini Yonivyapad W.S.R To Dysmenorrhea. International Ayurvedic Medical Journal \{online\} 2020 \{cited December, 2020\} Available from:

http://www.iamj.in/posts/images/upload/5232_5241.pdf 